\title{
Numerical response of the Common Buzzard Buteo buteo to the changes in abundance of small mammals
}

\author{
LÁSZLÓ TÓTH
}

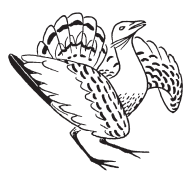

László Tóth 2014. Numerical response of the Common Buzzard Buteo buteo to the changes in abundance of small mammals. - Ornis Hungarica 22(1): 48-56.

Abstract I investigated the numerical response of the Common Buzzard to variations in density of small mammals. The study was carried out at the Hortobágy region in 2000-2001. During nest visiting periods clutch size, number of hatched and fledged young were recorded. Population of small mammals were also monitored by live-trapping. Effect of weather on the survival of overwintering rodents was also investigated. There was significant difference in clutch size between 2000 and 2001 (means 2.3 and 3.1). It can be explained by the remarkable differences in abundance of small mammal populations between the two years. The density of rodents was very low (9 specimen/ha) in 2000. During 2001 the amount of small mammals has increased more than eightfold ( 76 specimen/ha). In February and March, 2000 there were 4 short mild periods alternating with 4 freezing periods, when distribution of significant precipitation (6-8 $\mathrm{mm}$ rainfall in each) coincided with the mild periods. Thus the overwintering population almost extincted from the area because the tunnel complexes of voles are repeatedly flooded and huge part of the animals died, resulting very low density during the breeding season. In 2001 there was no such alternating periods, mild weather started 3 weeks earlier, thus voles overwintered successfully and their numbers increased rapidly producing a peak during the breeding season.

Keywords: Common Vole, effect of weather, prey density, reproductive success, resident raptor

Összefoglalás A kisemlősök denzitás változásainak az egerészölyv reprodukciójára gyakorolt hatását (un. numerikus választ) vizsgáltam a Hortobágyon, 2000-2001-ben. A fészekellenőrzések során regisztráltam a lerakott tojások, valamint a kikelt és a kirepült fiókák számát. Az egyik legfontosabb zsákmánycsoport, a kisemlősök állomány változásait élvefogó csapdázással monitoroztam. Vizsgáltam az időjárásnak az áttelelő kisemlősök túlélésére gyakorolt hatását is. Az ölyvek átlagos fészekalja a két évben szignifikánsan különbözött: 2000-ben 2,3, míg 2001-ben 3,1 tojás volt. Ez a kisemlősök - 2000-ről 2001-re bekövetkezett - jelentős mértékủ állománynövekedésével magyarázható. 2000-ben nagyon alacsony volt a kisemlösök egyedszáma ( 9 példány/ha), míg 2001ben ennek nyolcszorosát regisztráltam (76 példány/ha). A kisemlősök egyedszámában tapasztalt óriási eltéréseket a vizsgált két év tél végi-tavasz eleji időjárási különbségei okozhatták. 2000 február-márciusában, a napi minimum hőmérsékleteket tekintetve, 4 rövid, enyhe periódus váltakozott 4 fagypont alattival, ugyanakkor az enyhe időszakokban jelentős mennyiségü $(6-8 \mathrm{~mm})$ eső is hullott. Ekkor az áttelelő kisemlősök járatai ismételten beáztak, az állatok megfáztak, kihűltek, szinte kipusztultak a területről, ezért létszámuk a költési időszakban is rendkívül alacsony volt. 2001-ben a tél vége sokkal enyhébb volt, 3 héttel korábban emelkedtek fagypont fölé a napi minimum hömérsékletek, mint 2000-ben, nem alakultak ki váltakozó hideg-meleg időszakok sem. Ez kedvezően hatott az áttelelő kisemlősökre, létszámuk gyorsan emelkedett és nyár elejére mezei pocok gradáció alakult ki.

Kulcsszavak: időjárás hatása, mezei pocok, ragadozó madár, reprodukciós siker, zsákmány sűrüség

Institute of Agricultural and Environmental Sciences, Károly Róbert College, 3200 Gyöngyös, Mátrai út 36. e-mail: ltoth@karolyrobert.hu 


\section{Introduction}

The relationships between predators and variations in prey density can be separated into two types, numerical and functional responses, with the former describing how the per-capita reproductive rate changes with resource density and the latter how the consumption rate of individual consumers changes with respect to resource density (Solomon 1949). Numerical response may result by two different mechanism: i) increased rate of predator reproduction when prey is abundant or ii) attraction of predators to prey aggregations. The latter, the aggregational response of nomadic specialist predators usually occures without time lags, as their numerical responses are based on mobility, tracking changes in prey density without a time lag (Korpimäki $\&$ Norrdahl 1991). Delayed numerical response of resident generalist predators to increase in prey abundance is characterized by a time lag through higher natality and lower mortality (Goszczynski 1977). Delayed numerical response has been documented in resident mammalian predators (Korpimäki et al. 1991, Korpimäki \& Krebs 1996, Krebs 1996, O’Donoghue et al. 1997), and in birds of prey as well (Keith et al. 1977, Doyle \& Smith 1994, 2001, Rohner 1995, Nielsen 1999, 1996, Rohner et al. 2001). Three types of functional responses - linear, convex and sigmoid - are distinguished according to the nature of relationship between predation rate and prey density (Holling 1959). The functional response is mostly determined by foraging and behavior of the predator (Andersson \& Erlinge 1977, Korpimäki \& Norrdahl 1991). Numerical and functional responses have been shown in the same species as well (Luttich et al. 1971, Village 1987). Most studies of generalist predators have focussed on their functional response to only one prey species (Salamolard et al. 2000), however consumption by a generalist predator is expected to depend on the densities of all its major prey species (Yodzis 1994, Smout et al. 2010).

In this paper I investigate the response of a resident raptor, the Common Buzzard to variations in density of its main prey in the Hortobágy region, Hungary with the comparison of breeding performance of 2000 and 2001. There was great difference in density of rodents - which is the most important prey type of the species in the Great Hungarian Plain (Palatitz \& Tóth 2003) between the two years. Moreover, my aim was to investigate the effect of weather on population dynamics of small mammals i.e. the role of winter/spring temperature and precipitation in the survival/abundance of overwintering animals which determines the population size of rodents later, during the breeding season.

\section{Material and methods}

\section{Study area and species}

The study was carried out in the Great Hungarian Plain at Hortobágy region during 2000-2001. The study area covers about $200 \mathrm{~km}^{2}$ and is dominated by intensively cultivated fields, arable lands, grasslands and pastures. The region is one of the least forested part of Hungary. Buzzards bred in planted tree lines and forest patches with few hectare extension. There is only one large natural forest (200 hectares) in the study area near Ohat village.

The Common Buzzard is the most common raptor species in Hungary. The multi- 
plication of the breeding populations since the 1980 s is the result of the decrease of human persecution, the good adaptability of the species and the previous wood plantation programmes in the plains that enabled the species to spread in the lowlands (Tóth 2009). The number of breeding pairs exceeds 20000 (Ecsedi \& Sándor 2004).

\section{Breeding performance and small mammal abundance}

In March when birds reconstructed old nest or built new ones the study area was eximaned to find the occupied nests each year. The founded nests were visited by climbing 5-7 times during the breeding season to record clutch size, number of hatched and fledged young.

Main food supply i.e. the population size and changes of small mammals were also monitored in one hectare large sampling area of a grassland in the centre of the study area. At the sampling area a 1 hectare $(100 \times 100 \mathrm{~m})$ live-trapping grid was established, consisting of 121 livetraps in a $11 \times 11$ configuration with $10 \mathrm{~m}$ spacing. The trapping session was in June and it lasted 4 days. Traps were checked three times per day - in the morning, at noon and in the evening (traps were opened overnight as well). Individuals were uniquely marked with claw cutting applying a code table to distinguish the recaptured animals individually. Captured animales were identifed on species level. To assess population size I used the Minimum Number Alive (MNA) method introduced by Krebs (1966) for capture-mark-recapture data.

\section{Data on weather conditions and statistical analysis}

To study the effect of weather on the overwintering population of small mammals, data on weather conditions (from $1^{\text {st }}$ February to $30^{\text {th }}$ April in 2000 and 2001) were analysed. Daily minimum temperature values (in ${ }^{\circ} \mathrm{C}$ ) and daily amount of precipitation (in $\mathrm{mm}$ ) come from the nearest meteorological station of the Hungarian Meteorological Service in Debrecen, 45-50 km away from the center of the study area (available from the web site - under the code 12882099999 DEBRECEN - in both years: ftp://ftp.ncdc. noaa.gov/pub/data/gsod/).

Comparing the clutch size, number of hatchlings and fledglings between 2000 and 2001. I used generalized linear model (GLM) with quasipoisson error distribution (Venables 2002). The statistical analysis was carried out in R 3.0.2 (R Core Team 2013). Completed first clutches were involved only, when mean values of clutch size were calculated. Moreover, mean number of hatchlings and fledglings were calculated based on those nests where one young hatched from eggs at least.

\section{Results}

\section{Breeding success}

There was considerable difference regarding the number of breeding pairs between 2000 and 2001. In 2000, 7 buzzard pairs started to breed on the study area, while during 2001 there were 13 breeding attempts. In 2000, 1 breeding attempt out of 7 failed during the incubation period, it was exluded from the analysis because the final number of laid eggs was unknown (Table 1). In 


\begin{tabular}{|l|c|c|c|c|c|c|c|}
\hline Year & \multicolumn{3}{|c|}{2000} & \multicolumn{3}{c|}{2001} & \\
\hline & $\overline{\boldsymbol{x}}$ & SD & $\mathbf{N}$ & $\overline{\boldsymbol{x}}$ & SD & $\mathbf{N}$ & P-value \\
\hline Number of laid eggs & 2.3 & 0.52 & 6 & 3.1 & 0.86 & 11 & 0.0124 \\
\hline Number of hatched young & 2.3 & 0.52 & 6 & 2.7 & 1.41 & 9 & 0.3355 \\
\hline Number of fledged young & 1.8 & 0.98 & 6 & 2.0 & 1.33 & 9 & 0.4236 \\
\hline
\end{tabular}

Table 1. Breeding results of the Common Buzzard at Hortobágy region in 2000 and 2001 ( $\bar{x}=$ mean, $\mathrm{SD}=$ standard deviaton, $\mathrm{N}$ = sample size, $\mathrm{P}$-value from GLM)

1. táblázat Az egerészölyv költési eredményei 2000-ben és 2001-ben a Hortobágy térségében. Az adatok fészkenkénti átlagok ( $\bar{x}=$ átlag, $\mathrm{SD}=$ szórás, $\mathrm{N}$ = fészkek száma, $\mathrm{P}$-érték GLM-ből)

2001, 2 breeding attempts out of 13 were exluded when mean clutch size was calculated due to similar reason and another 2 nests with completed clutches were exluded from the analyses regarding mean values of hatched and fledged young due to nest failure during the incubation period (Table 1). Mean values of the investigated three breeding parameters were greater in 2001 than in 2000, however significant difference was found in the mean number of laid eggs only $(\mathrm{P}=0.01242)$, buzzards laid approximately one more egg on average in 2001 (Table 1).

\section{Abundance of small mammal community}

In 2000, the species diversity and the abundance of small mammal community were very low in the study area. Estimated population size (MNA) of small mammals was less than 10 specimen which belonged to three different species: 6 Common Voles (Microtus

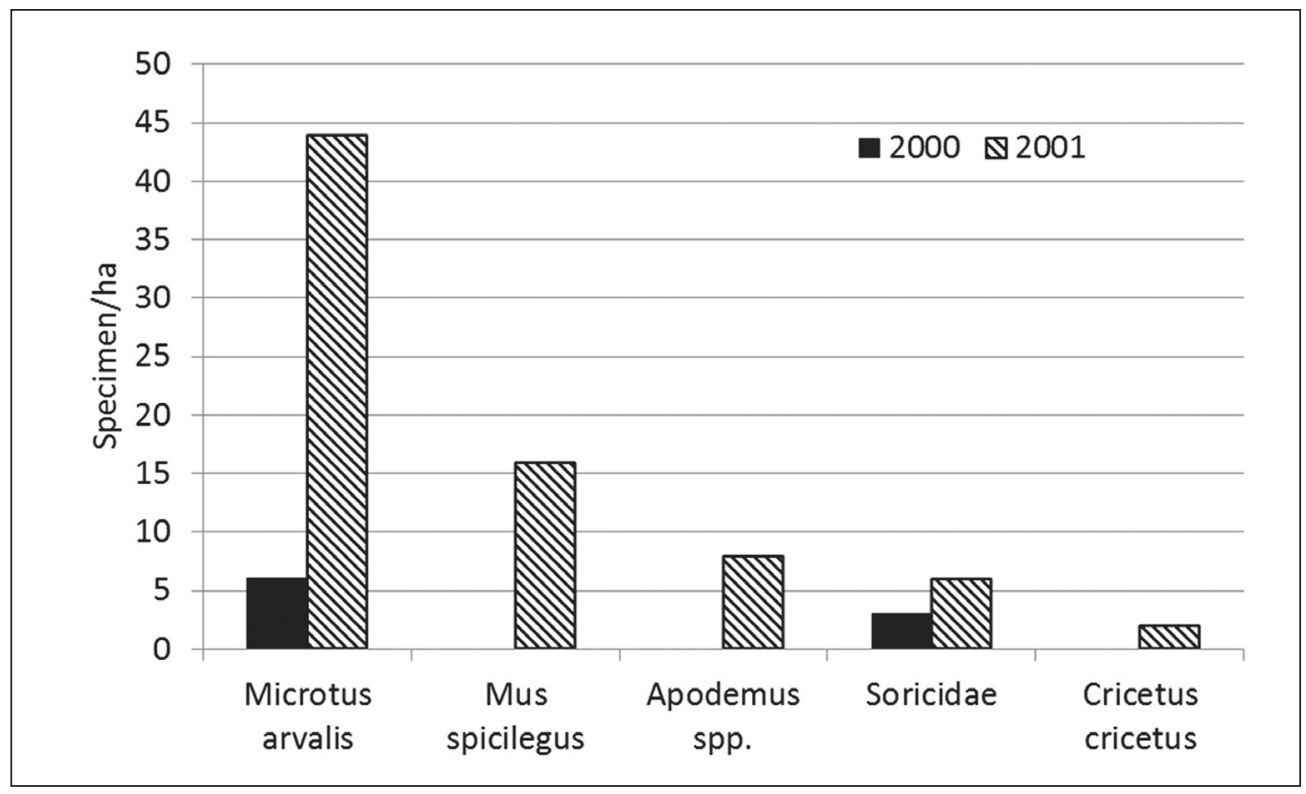

Figure 1. Density of small mammals during the breeding season in 2000 and 2001

1. ábra A kisemlősök egyedsűrűsége a költési időszakban 2000-2001-ben 


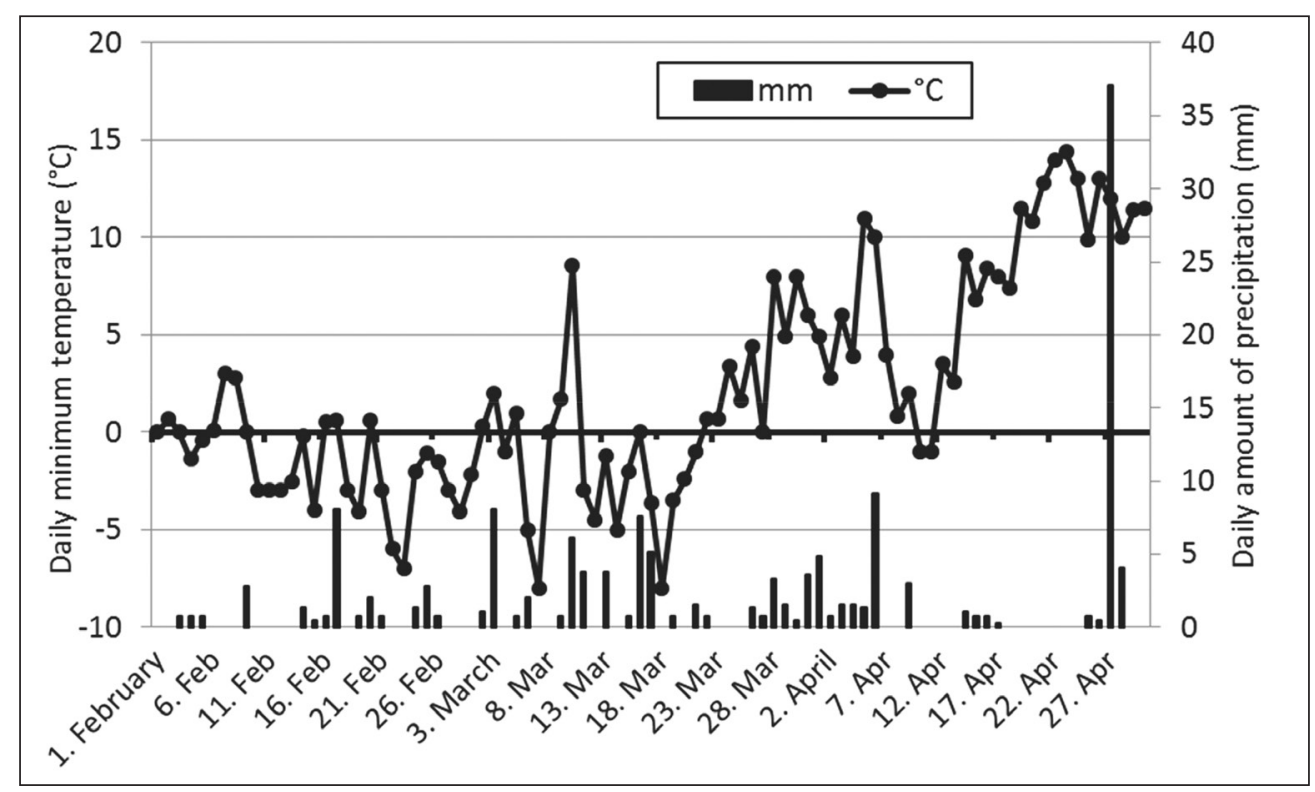

Figure 2. Daily minimum temperature and daily amount of precipitation in 2000 , from February to April 2. ábra A napi minimum hőmérsékletek és a napi csapadék mennyisége 2000-ben, februártól áprilisig

arvalis), 2 Common Shrews (Sorex araneus) and 1 Bi-coloured White-toothed Shrew (Crocidure leucodon) were trapped (Figure 1). In 2001 there were considerable changes in species composition and abundance of small mammals. During the breeding season the amount of small mammals increased eightfold comparing to previous year, the total number of trapped animals (MNA) was 76 specimen (Figure 1). Captured species were Common Vole, Steppe Mouse (Mus spicilegus), Striped Field Mouse (Apodemus agrarius), Wood Mouse (A. sylvaticus), Yellow-necked Mouse (A. flavicollis), Pygmy Field Mouse (A. uralensis), Common Shrew, Bi-coloured White-toothed Shrew, Pygmy Shrew (S. minutus) and Common Hamster (Cricetus cricetus). However, Common Vole and Steppe Mouse dominated the food supply, these two species accounted for $79 \%$ of trapped animals (44 and 16 specimen, respectively), while proportion of the other 8 species altogether was $21 \%$ (Figure 1).

\section{Weather conditions}

There were some differences in weather conditions from February to April between 2000 and 2001. Average ( \pm SD) monthly minimum temperature was similar in February (in 2000: $-1.6 \pm 2.4^{\circ} \mathrm{C}$, in 2001: $-2.0 \pm 3.5$ ${ }^{\circ} \mathrm{C}$ ), while in March and April these values differed considerably. Regarding the minimum values, March was colder in 2000 by $3.1{ }^{\circ} \mathrm{C}$ than in 2001 (average minimum: $0.0 \pm 4.3{ }^{\circ} \mathrm{C}$ and $3.1 \pm 3.3{ }^{\circ} \mathrm{C}$, respectively). In April, the year of 2000 was warmer than 2001 (average minimum: 7.8 44.6 ${ }^{\circ} \mathrm{C}$ and $5.1 \pm 3.1{ }^{\circ} \mathrm{C}$, respectively). Important difference can be observed in changes of daily minimum values. In 2000 the minimum temperature stayed below zero till $21^{\text {th }}$, March, however there were 5 short periods (7-8., 16-17. February, 2-3., 9-10., 16. March) when values exceeded zero (Figure 2). In 2001 the last decade of February was rather cold, but from the $2^{\text {nd }}$ of March daily 


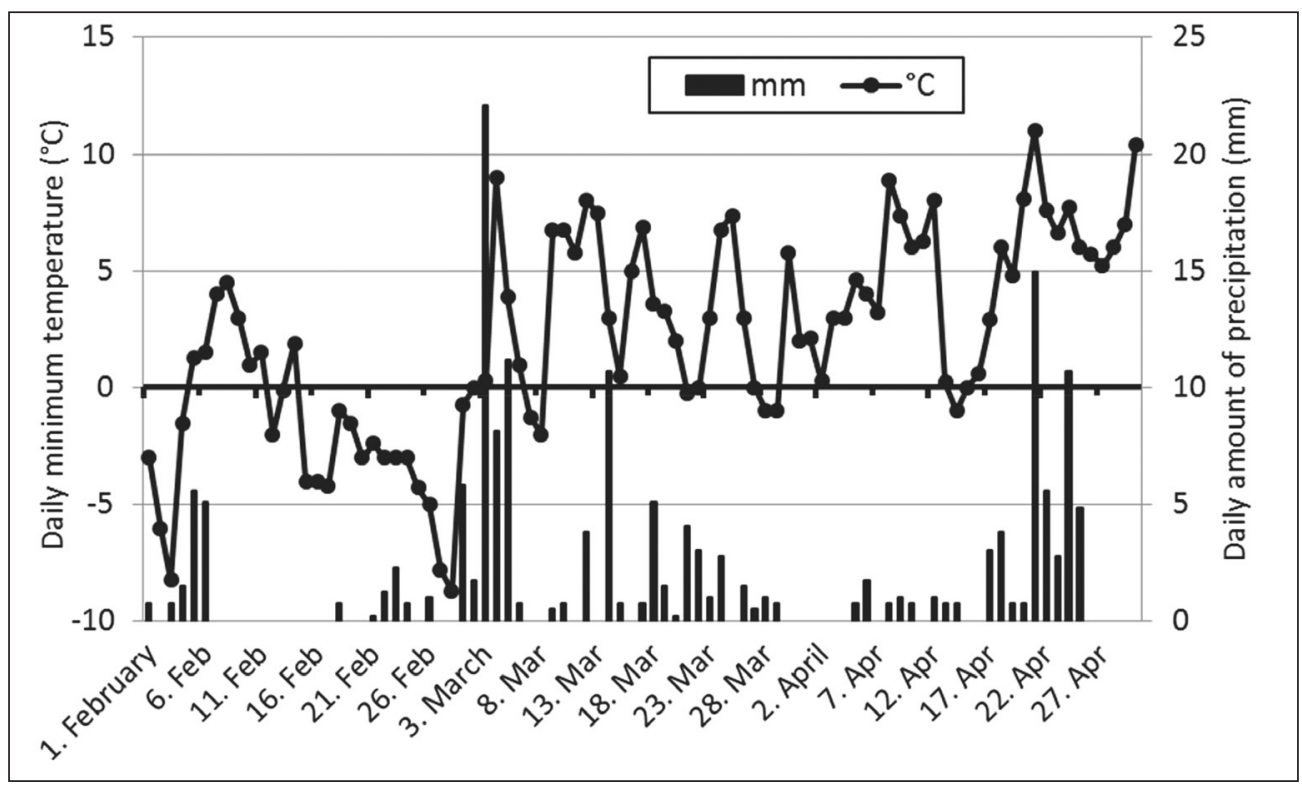

Figure 3. Daily minimum temperature and daily amount of precipitation in 2001, from February to April 3. ábra A napi minimum hőmérsékletek és a napi csapadék mennyisége 2001-ben, februártól áprilisig

minimum temperature exceeded zero - almost permanently - i.e. mild weather started 3 weeks earlier than in the previous year (Figure 3).

Monthly amounts of precipitation were similar during February in 2000 and 2001 (24 and $20 \mathrm{~mm}$, respectively), during March and April there were differences between the two years (2000: 54, $67 \mathrm{~mm}, 2001: 89,55 \mathrm{~mm}$ ). Distribution of precipitation differed considerably during February and March between the two years: in 2000 there were 4 days (17. February, 3., 10., 16. March) when the amount of precipitation was significant (exceeded $6 \mathrm{~mm}$ ), while in 2001 there were 2 occasions (3-5., 14. March) only (Figure 2, 3).

\section{Discussion}

Breeding population size and reproductive success of raptors are determined by the availability of nesting sites, food supp- ly and weather conditions (Korpimäki 1985, Kostrzewa \& Kostrzewa 1990, Korpimäki \& Norrdahl 1991, Butet \& Leroux 1993, Jędrzejewski et al. 1994, Korpimäki 1994, Salamolard et al. 2000, Reif et al. 2001, Tóth \& Palatitz 2003, Millon \& Bretagnolle 2008, Millon et al. 2008, also see a review in Csörgő et al. 2012). Nest predation can also play an important role regarding breeding success in fragmented habitats, as well (Chalfoun et al. 2002). I found considerable differences in the number of breeding pairs and their breeding success of the studied buzzard population between 2000 and 2001. In 2001 the number of breeding pairs increased twofold comparing to the previous year (from 7 to 13 pairs). There was significant difference in clutch size mean number of laid eggs was greater in 2001 than in 2000 . These changes can be explained by the remarkable differences in abundance of small mammal population between the two years. The density of rodents 
was very low in 2000 ( 9 specimen/ha). During 2001 the amount of small mammals has increased more than eightfold (76 specimen/ha). Particularly the population change of the Common Vole was drastic, their density has increased from 6 to 44 specimen/ ha. However, there were no significant differences regarding the number of hatchlings and fledglings between the two years. This can be resulted by the higher predation rate in 2001. That year 4 out of 13 nests failed (31\%) due to predation in contrast with $14 \%$ of 2000. As a result, success of chick raising decreased (there were no hatched young in four nests), thus predation could mask the positive effect of high vole density on reproduction in 2001.

Weather can affect reproductive success either directly - failure of eggs and young due to heavy rainfall and low temperature or indirectly, e.g. decreasing food availability. Weather conditions during winter and spring determine the overwintering success of small mammal populations. In this respect the most important factors are the changes of temperature and precipitation at the end of winter and the beginning of spring. Overwintering population faces the highest risk when short periods of temperature below and above zero alternates and there is significant rainfall during the mild periods. The tunnel complexes of voles are flooded and huge part of the overwintering animals may die by the cold. During 2000 (in February and March) there were 4 short periods (16-17. February, 2-3., 9-10., 16. March) when mimimum temperature exceeded zero alternating with 4 freezing periods 3-4 degree below zero and lasted 12-14 days. The distribution of significant precipitation (6-8 $\mathrm{mm}$ rainfall) coincided with the 4 mild periods, thus the overwintering population almost extincted from the area resulting very low density of small mammals during the breeding season. In 2001 the above mentioned conditions were much more favourable for the small mammal population. There was no alternating mild and freezing periods, mild weather started 3 weeks earlier than in the previous year (March was extraordinaly cold in 2000). Thus voles overwintered successfully and their numbers increased rapidly producing a peak during the breeding season.

\section{Acknowledgement}

I thank the Hortobágy National Park Directorate for issuing the research permission. Special thank to Márta Bera, Miklós Dudás, Róbert Kiss, Péter Palatitz and Szabolcs Solt for their assistance during the field work. I would like to express my gratitude to referees for their useful comments on the manuscript. I am grateful to Andrea Harnos for her help provided in the statistical analyses. The study was financially supported by the Department of Game Management and Fishery, Ministry of Agriculture and Regional Development. 


\section{References}

Andersson, M. \& Erlinge, S. 1977. Influence of predation on rodent populations. - Oikos 29: 591-597.

Butet, A. \& Leroux. A. B. A. 1993. Effect of prey on a predators breeding success - a 7-year study on Common Vole (Microtus arvalis) and Montagus Harrier (Circus pygargus) in a west France marsh. - Acta Oecologica-International Journal of Ecology 14: 857-865.

Chalfoun, A. D., Thompson, F. R. \& Ratnaswamy M. J. 2002. Nest predators and fragmentation: a review and meta-analysis. - Conservation Biology 16: 306-318.

Csörgő, T., Zornánszky, R., Szép, T. \& Fehérvári, P. 2012. Should the Common Buzzard be hunted? Ornis Hungarica 20(2): 1-12.

Doyle, F. I. \& Smith, J. M. N. 1994. Population responses of northern goshawks to the 10-year cycle in numbers of snowshoe hares. - Studies of Avian Biology 16: 122-129.

Doyle, F. I. \& Smith, J. N. M. 2001. Raptors and scavengers. - In: Krebs, C. J., Boutin, S. \& Boonstra, R. (eds.) Ecosystem dynamics of the boreal forest. The Kluane Project. - Oxford University Press, pp. 377-404.

Ecsedi, Z. \& Sándor, I. 2004. Egerészölyv [Common Buzzard]. - In: Ecsedi, Z. (ed.) 2004. A Hortobágy madárvilága [Birds of Hortobágy]. - Hortobágy Természetvédelmi Egyesület, Winter Fair, Balmazújváros-Szeged, pp. 212-214. (in Hungarian)

Goszczynski, J. 1977. Connections between predatory birds and mammals and their prey. - Acta Theriologica 22: 399-430.

Holling, C. S. 1959. Some characteristics of simple types of predation and parasitism. - Canadian Entomologist 91: 385-398.

Jędrzejewski, W., Szymura, A. \& Jędrzejewska, B. 1994. Reproduction and food of the Buzzard Buteo buteo in relation to the abundance of rodents and birds in Białowieża National Park, Poland. Ethology Ecology \& Evolution 6: 179-190.

Keith, L. B., Todd, A. W. \& Brand, C. J. 1977. An analysis of predation during a cyclic fluctuation on snowshoe hares. $-13^{\text {th }}$ International Congress of Game Biology 13: 163-174.

Korpimäki, E. 1985. Rapid tracking of microtine populations by their avian predators: possible evidence for stabilizing predation. - Oikos 45: 281-284.

Korpimäki, E. 1994. Rapid or delayed tracking of multi-annual vole cycles by avian predators? - Journal of Animal Ecology 63: 619-628.

Korpimäki, E. \& Krebs, C. J. 1996. Predation and population cycles in small mammals. A reassess- ment of the predation hypothesis. - BioScience 46: 754-764.

Korpimäki, E. \& Norrdahl, K. 1991. Numerical and functional responses of Kestrels, Short-Eared Owls, and Long-Eared Owls to vole densities. Ecology 72: 814-826.

Korpimäki, E., Norrdahl, K. \& Rinta-Jaskari, T. 1991. Responses of stoats and least weasels to fluctuating food abundance: is the low phase of the vole cycle due to mustelid predation? - Oecologia 88 : 552-561.

Kostrzewa, A. \& Kostrzewa, R. 1990. The relationship of spring and summer weather with density and breeding performance of the Buzzard Buteo buteo, Goshawk Accipiter gentilis and Kestrel Falco tinnunculus. - Ibis 132: 550-559.

Krebs, C. J. 1966. Demographic changes in fluctuating populations of Microtus californicus. - Ecological Monographs 36: 239-273.

Krebs, C. J. 1996. Population cycles revisited. - Journal of Mammalogy 77: 8-24.

Luttich, S. N., Keith, L. B. \& Stephenson, J. D. 1971. Population dynamics of the Red-tailed Hawk ( $\mathrm{Bu}$ teo jamaicensis) at Rochester, Alberta. - The Auk 88: 75-87.

Millon, A. \& Bretagnolle, V. 2008. Predator population dynamics under a cyclic prey regime: numerical responses, demographic parameters and growth rates. - Oikos 117: 1500-1510.

Millon, A., Arroyo, B. E. \& Bretagnolle, V. 2008. Variable but predictable prey availability affects predator breeding success: natural versus experimental evidence. - Journal of Zoology 275: 349-358.

Nielsen, O. 1999. Gyrfalcon predation on ptarmigan: numerical and functional responses. - Journal of Animal Ecology 68: 1034-1050.

O’Donoghue, M., Boutin, S. \& Krebs, C. J. 1997. Numerical responses of coyotes and lynx to the snowshoe hare cycle. - Oikos 80: 150-162.

Palatitz, P. \& Tóth, L. 2003. Diet variations of three sympatric raptor species in relation to small rodent densities. $-6^{\text {th }}$ World Conference on Birds of Prey and Owls (Budapest, Hungary), Abstracts: p. 5.

R Core Team 2013. R: A language and environment for statistical computing. R Foundation for Statistical Computing, Vienna, Austria. URL http:// www.R-project.org/.

Reif, V., Tornberg, R., Jungell, S. \& Korpimäki, E. 2001. Diet variation of Common Buzzards in Finland supports the alternative prey hypothesis. Ecography 24: 267-274. 
Rohner, C. 1995. Great Horned Owls and Snowshoe Hares: what causes the time lag in the numerical response of predators to cyclic prey? - Oikos 74 : 61-68.

Rohner, C. 1996. The numerical response of Great Horned Owls to the Snowshoe Hare cycle: consequences of non-territorial 'floaters' on demography. - Journal of Animal Ecology 65: 359-370.

Rohner, C., Doyle, F. I. \& Smith, J. N. M. 2001. Great Horned Owls. - In: Krebs, C. J., Boutin, S. \& Boonstra, R. (eds.) Ecosystem dynamics of the boreal forest. The Kluane Project. - Oxford University Press, pp. 340-376.

Salamolard, M., Butet, A., Leroux, A. \& Bretagnolle, V. 2000. Responses of an avian predator to variations in prey density at a temperate latitude. Ecology 81: 2428-2441.

Smout, S., Asseburg, C., Matthiopoulos, J., Fernández, C. \& Redpath, S. 2010. The functional response of a generalist predator. - PLoS ONE 5(5): e10761. DOI: 10.1371/journal.pone.0010761

Solomon, M. E. 1949. The natural control of animal populations. - Journal of Animal Ecology 18: $1-35$.
Tóth, L. 2009. Egerészölyv [Common Buzzard]. - In: Csörgő, T., Karcza, Zs., Halmos, G., Magyar, G., Gyurácz, J., Szép, T., Bankovics, A., Schmidt, A. \& Schmidt, E. (eds.) 2009. Magyar madárvonulási atlasz [Hungarian Bird Migration Atlas]. - Kossuth Kiadó, Budapest, pp. 221-224. (in Hungarian with English Summary)

Tóth, L. \& Palatitz, P. 2003. Effect of rodent cycles on the reproduction of Buzzard and Goshawk. $-6^{\text {th }}$ World Conference on Birds of Prey and Owls (Budapest, Hungary) Abstracts: p. 5.

Venables, W. N. \& Ripley, B. D. 2002. Modern Applied Statistics with S. $-4^{\text {th }}$ Edition, Springer, New York

Village, A. 1987. Numbers, territory-size and turnover of Short-eared Owls Asio flammeus in relation to vole abundance. - Ornis Scandinavica 18: 198204.

Yodzis, P. 1994. Predator-prey theory and management of multispecies fisheries. - Ecological Applications 4: 51-58.

$\mathrm{ftp}: / / \mathrm{ftp} . n c d c . n o a a . g o v / p u b /$ data/gsod/

http://www.ncdc.noaa.gov/cgi-bin/res40.pl?page=gsod. html

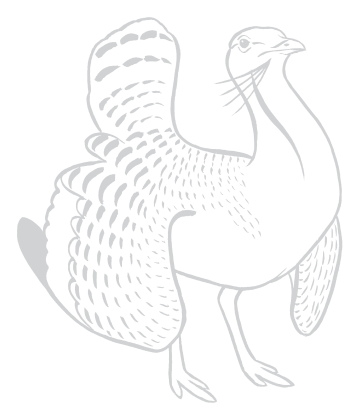

